\title{
Differential expression of gonadotropin and prolactin antigens by GHRH target cells from male and female rats
}

\author{
G V Childs, G Unabia, B T Miller and T J Collins \\ Department of Anatomy and Neurosciences, University of Texas Medical Branch, Galveston, Texas 77555-1043, USA \\ (Requests for offprints should be addressed to G V Childs)
}

\begin{abstract}
There is a 2- to 3-fold increase in luteinizing hormonebeta $(\mathrm{LH} \beta)$ or follicle-stimulating hormone-beta (FSH $\beta$ ) antigen-bearing gonadotropes during diestrus in preparation for the peak LH or FSH secretory activity. This coincides with an increase in cells bearing LH $\beta$ or FSH $\beta$ mRNA. Similarly, there is a 3-to 4-fold increase in the percentage of cells that bind GnRH. In 1994, we reported that this augmentation in gonadotropes may come partially from subsets of somatotropes that transitionally express LH $\beta$ or FSH $\beta$ mRNA and GnRH-binding sites. The next phase of the study focused on questions relating to the somatotropes themselves. Do these putative somatogonadotropes retain a somatotrope phenotype? As a part of ongoing studies that address this question, a biotinylated analog of GHRH was produced, separated by HPLC and characterized for its ability to elicit the release of $\mathrm{GH}$ as well as bind to pituitary target cells. The biotinylated analog (Bio-GHRH) was detected cytochemically by the avidin-peroxidase complex technique. It could be displaced by competition with 100-1000 nM GHRH but not corticotropin-releasing hormone or GnRH. In cells from male rats exposed to $1 \mathrm{nM}$ Bio-GHRH, $28 \pm 6 \%$ (mean \pm s.D) of pituitary cells exhibited label for BioGHRH (compared with $0.8 \pm 0.6 \%$ in the controls). There were no differences in percentages of GHRH target cells in populations from proestrous $(28 \pm 5 \%)$ and estrous $(25 \pm 5 \%)$ rats. Maximal percentages of labeled cells were seen following addition of $1 \mathrm{nM}$ analog for $10 \mathrm{~min}$. In dual-labeled fields, GHRH target cells contained all major pituitary hormones, but their expression of ACTH and TRH was very low (less than 3\% of the pituitary cell
\end{abstract}

population) and the expression of prolactin (PRL) and gonadotropins varied with the sex and stage of the animal. In all experimental groups, $78-80 \%$ of Bio-GHRHreactive cells contained GH ( $80-91 \%$ of GH cells). In male rats, $33 \pm 6 \%$ of GHRH target cells contained PRL ( $37 \pm 9 \%$ of PRL cells) and less than $20 \%$ of these GHRH-receptive cells contained gonadotropins $(23 \pm 1 \%$ of $\mathrm{LH}$ and $31 \pm 9 \%$ of FSH cells). In contrast, expression of PRL and gonadotropins was found in over half of the GHRH target cells from proestrous female rats $(55 \pm 10 \%$ contained PRL; $56 \pm 8 \%$ contained FSH $\beta$; and $66 \pm 1 \%$ contained LH $\beta$ ). This reflected GHRH binding by $71 \pm 2 \%$ PRL cells, $85 \pm 5 \%$ of $\mathrm{LH}$ cells and $83 \pm 9 \%$ of FSH cells. In estrous female rats, the hormonal storage patterns in GHRH target cells were similar to those in the male rat. Because the overall percentages of cells with Bio-GHRH or GH label do not vary among the three groups, the differences seen in the proestrous group reflect internal changes within a single group of somatotropes that retain their GHRH receptor phenotype. Hence, these data correlate with earlier findings that showed that somatotropes may be converted to transitional gonadotropes just before proestrus secretory activity. The LH and FSH antigen content of the GHRH target cells from proestrous rats demonstrates that the $\mathrm{LH} \beta$ and FSH $\beta$ mRNAs are indeed translated. Furthermore, the increased expression of PRL antigens by these cells signifies that these convertible somatotropes may also be somatomammotropes.

Journal of Endocrinology (1999) 162, 177-187

\section{Introduction}

During the estrous cycle, there is a rise and fall in the concentration of gonadotropes in the anterior pituitary (Childs et al. 1987, 1992a,b, Lloyd \& Childs 1988, Childs 1994, 1997). The highest percentages of gonadotropes detected by their content of luteinizing hormone-beta $(\mathrm{LH} \beta)$ or follicle-stimulating hormonebeta $(\mathrm{FSH} \beta)$ antigens are found the day before the proestrus peak secretory activity. After secretion, stores of gonadotropins decline below threshold levels for detection by immunolabeling resulting in a 2 -fold decrease in percentages of gonadotropes by the morning of metestrus. Nevertheless, gonadotropes can still be detected by their expression of gonadotropin beta subunit mRNAs which peaks during and after the high secretory activity (Childs et al. 1992a,b, 1994a, Childs 1997). 
The transcriptional activity early in the cycle replenishes the identifiable, immunoreactive gonadotropes as the LH and FSH stores are recovered by translation of the mRNA during diestrus. In 1994, studies from this laboratory showed that both gonadotrope and growth hormone $(\mathrm{GH})$ cells contributed to these new cells during diestrus (Childs et al. 1994a, Childs 1997). This was detected by dual labeling for $\mathrm{LH} \beta$ or FSH $\beta$ mRNA and gonadotropin or $\mathrm{GH}$ antigens. These data suggested that $40-60 \%$ of $\mathrm{GH}$ cells may contribute to the population of gonadotropes in preparation for the LH or FSH secretory activity.

Later studies demonstrated binding sites for a biotinylated analog of gonadotropin-releasing hormone (Bio-GnRH) on cells with GH antigens (Childs et al. 1994b). The GH cells increased expression of Bio-GnRHbinding sites to reach peak levels of about $40 \%$ of somatotropes by the afternoon of diestrus. This supported the hypothesis that these cells had the potential to respond to the gonadotropin secretagogues. Recent evidence suggests that the GnRH receptors may also serve a regulatory function in GH cells. Ghosh et al. (1996) showed that $\mathrm{GnRH}$ can stimulate $\mathrm{GH}$ secretion from sheep anterior pituitary cell cultures. Also, Villalobos et al. (1997) reported that $4 \mathrm{nM} \mathrm{GnRH}$ stimulated calcium influx in over $30 \%$ of GH cells from male rat pituitaries.

Most recently, we showed that inhibin decreased the percentages of $\mathrm{GH}$ cells with $\mathrm{GnRH}$ binding in proestrous populations (Childs et al. 1997) while activin increased the percentages of cells that bound Bio-GnRH, including gonadotropes and GH cells (Childs \& Unabia 1997). These findings suggest possible mechanisms behind the changes in expression of GnRH-binding sites by somatotropes.

Activin is known to inhibit GH synthesis and secretion (Kitaoka et al. 1988, Bilezikjian et al. 1990, 1993, Billestrup et al. 1990, Struthers et al. 1992) and the proliferation of somatotropes (Billestrup et al. 1990). In view of its stimulatory effects on expression of $\mathrm{GnRH}$ receptors by GH cells (Childs \& Unabia 1997), we hypothesized that somatotropes might be stimulated to produce $\mathrm{GnRH}$ receptors early in the cycle (perhaps by activin and/or estradiol) and, at the same time, exhibit reduced activities related to $\mathrm{GH}$ secretion, such as expression of $\mathrm{GH}$ mRNA or GH-releasing hormone $(\mathrm{GHRH})$ receptors.

To test the last part of the above hypothesis, GHRHbinding sites were detected cytochemically by exposing living cells to Bio-GHRH (Childs et al. 1983, 1994b, Childs 1998). After fixation and detection of the analog on the cells, immunolabeling was used to identify the hormone produced by the cell. If our working hypothesis was correct, we expected to see lower expression of GHRH receptors by proestrous $\mathrm{GH}$ cells (compared with male rats or estrous female rats). We also expected to see little evidence for gonadotropin antigens in the remaining GHRH target cells. This report characterizes the potency of the biotinylated analogs of GHRH and also reports the hormone content of the GHRH target cells. The data show that percentages of Bio-GHRH-reactive cells do not vary with the experimental group. They also continue to store $\mathrm{GH}$ antigens. Furthermore the storage patterns of GHRH target cells from proestrous female rats correlate well with the known conversion of somatotropes to somatomammotropes along with the increased expression of LH and FSH mRNAs by GH cells (Childs et al. 1994a) just before ovulation.

\section{Materials and Methods}

\section{Production of Bio-GHRH}

Synthetic rat GHRH and the reagent biotinamidocaproate N-hydroxysuccinimide ester were purchased from Sigma Chemical Co. (St Louis, MO, USA). Biotinylation reactions were performed and the reaction products purified as previously described (Miller et al. 1997). Briefly, the reagent was dissolved in $0.025 \mathrm{ml}$ dimethylsulfoxide and added to the peptide which had been dissolved in $0.2 \mathrm{ml}$ $0.05 \mathrm{M}$ sodium phosphate buffer, $\mathrm{pH} 7$. Reactions were terminated by the addition of $0 \cdot 1 \%$ trifluoroacetic acid (TFA) and the entire reaction mixture was applied to a Vydac C18 reversed phase HPLC column (Vydac, Hesperia, CA, USA). Reaction products were eluted from the column with a linear gradient of acetonitrile in $0 \cdot 1 \%$ TFA, pooled based on absorbance at $215 \mathrm{~nm}$, and dried in a Speed-vac concentrator (Savant Instruments Inc., Holbrook, NY, USA). Determination of the number of biotin moieties linked to the GHRH derivatives was carried out through amino acid compositional analysis in the University of Texas Medical Branch Protein Chemistry Laboratory, as described (Miller et al. 1992, 1997). Automated amino acid sequence analysis of the modified peptides was performed as previously reported (Smith et al. 1991).

\section{Animal care protocol}

Cells from male and cycling female Sprague-Dawley rats were used for these studies. The rats were acclimated for 10 days in a constant light-controlled environment $(10 \mathrm{~h}$ on, $14 \mathrm{~h}$ off) and the cycling female rats were then tested daily for the stage of the estrous cycle, by vaginal smears. Rats in either proestrus or estrus stages were used only after each rat had completed at least two normal 4 day cycles. Rats were killed by decapitation within seconds of removal from their cage. The pituitaries were then removed and placed in defined medium as previously described (Childs et al. 1994a). They were then dissociated and plated overnight in defined media (Childs et al. 1994). The Animal Use and Care (ACUC) Protocol has been approved annually by the University ACUC committee. 
Tests of potency of Bio-GHRH derivatives

Cells plated in the above experiments were stimulated for $3 \mathrm{~h}$ in $0 \cdot 1-10 \mathrm{nM}$ GHRH or Bio-GHRH. Media were then removed and assayed for GH, with RIA kits from the NIH National Pituitary Agency Hormone Distribution Program using the kit instructions. GH media concentrations were expressed in terms of ng/ml NIDDKrGH-RP-Z (AFP-31908). The sensitivity of the assays was $0 \cdot 6-1 \cdot 0 \mathrm{ng} / \mathrm{ml}$ sample. In addition, in some experiments, media were assayed for LH and FSH with NIH kits according to previously published protocols (Childs et al. 1992b). Inter- and intra-assay variations were less than $10 \%$.

\section{Cytochemical detection of Bio-GHRH}

The initial sets of cytochemical tests involved exposure of cells from normal adult male or proestrous female rats to Bio-GHRH, testing both time of exposure and the concentration needed for optimal detection and labeling of the cell population. In later tests, cells from estrous female rats were used. The study was designed so that the same batch of Bio-GHRH was used in all experiments. In the tests of concentration, cells were exposed to $0 \cdot 1-10 \mathrm{nM}$ Bio-GHRH for $10 \mathrm{~min}$. In the study of time of exposure, cells were given $10 \mathrm{nM}$ Bio-GHRH for 1, 3, 10, 30 and $60 \mathrm{~min}$. Additional specificity controls were done in which $1 \mathrm{nM}$ Bio-GHRH was added with 100- to 1000-fold excess of native GHRH, corticotropin-releasing hormone $(\mathrm{CRH})$ or GnRH. The Bio-GHRH was diluted in Dulbecco's modified Eagle's medium, as described previously (Childs et al. 1994b).

After exposure to the analogs described in the previous paragraph, the cells were then fixed in $2.5 \%$ glutaraldehyde, washed in $0.1 \mathrm{M}$ phosphate buffer with sucrose and labeled with the avidin-biotin-peroxidase complex technique (Childs et al. 1994b, Childs \& Unabia 1997). The peroxidase reaction product was nickel-intensified diaminobenzidine, which produced a dense blue-black precipitate at the site of binding.

\section{Identification of pituitary target cells}

Optimization of the labeling protocol involved the determination of the minimal concentrations and times that labeled all the target cells (the plateau point). The first series of tests determined that maximal labeling was achieved with $1 \mathrm{nM}$ Bio-GHRH after $10 \mathrm{~min}$. This concentration and time was used in all subsequent dual labeling studies. The labeling for the Bio-GHRH was followed by immunolabeling for one of six pituitary hormones with immunoperoxidase techniques and diaminobenzidine, which is a contrasting colored peroxidase substrate as previously described (Childs et al. 1983, 1994b,

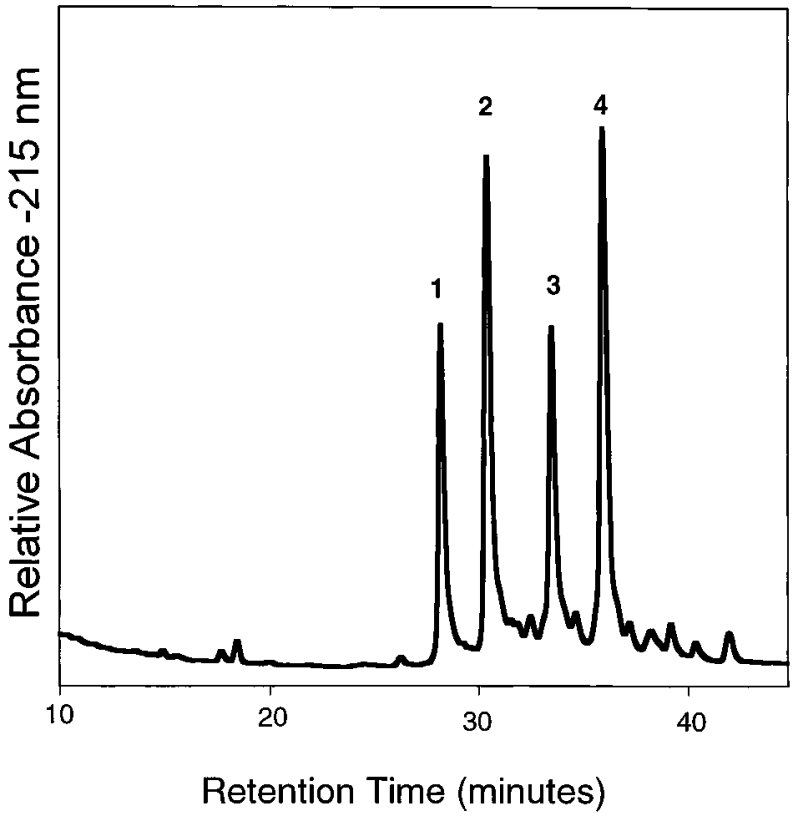

Figure $1 \mathrm{HPLC}$ of a reaction mixture of rat GHRH with biotinamidocaproate N-hydroxysuccinimide ester (70:1 reagent:peptide molar ratio for $8 \mathrm{~min}$ at room temperature). Peak 1 was unmodified GHRH. The remaining peaks contained analogs biotinylated on either Lys ${ }^{21}$ (peak 2), the N-terminus (peak 3), or on both Lys ${ }^{21}$ and the N-terminus (peak 4).

Childs \& Unabia 1997). The blue-black label for the BioGHRH was thereby distinguished from the orange-amber label for the pituitary hormones.

\section{Analysis of cytochemical data}

Cells that bound GHRH were counted in both male and proestrous female rats and expressed as a percentage of the total cells counted (150-200 cells per coverslip). Fields were scanned randomly with a $\times 100$ oil immersion objective and the first 150-200 cells encountered were counted with a blood cell counter noting each category of label (single-labeled cells, unlabeled cells, dual-labeled cells). We analyzed three coverslips/experiment. The data from the counts were placed in an EXEL file which automatically calculated the percentages of cells with each product (GHRH-binding sites or pituitary hormone), as well as percentages of cells labeled for both GHRH and a pituitary hormone. This tested the dual labeling protocol to insure that it was not adversely affecting the detection of either product. Differences between significant groups were compared by ANOVA. If the ANOVA F value was significant $(P<0 \cdot 05)$, then the Fischer's least significant difference posthoc test was run to detect differences between groups. Significant differences between groups were accepted if the $P$ value was $<0 \cdot 05$. 


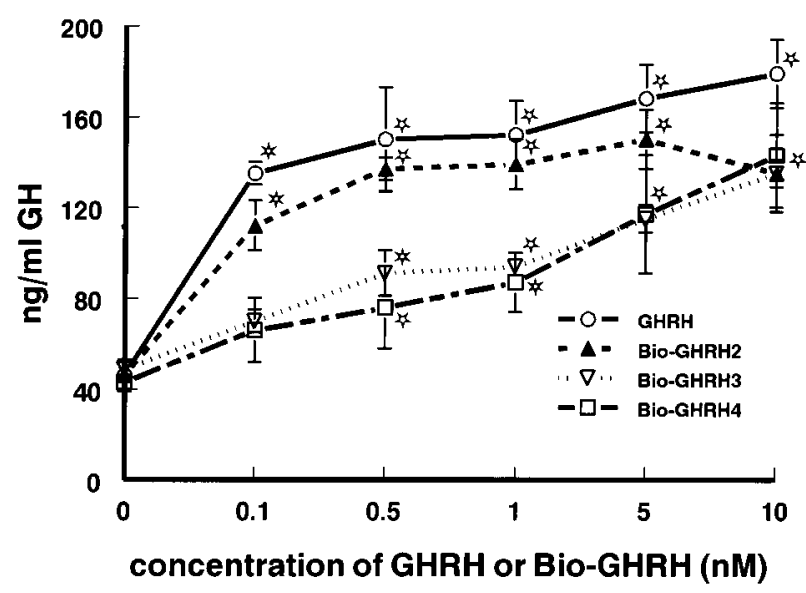

Figure 2 RIA of $\mathrm{GH}$ secretion after exposure to GHRH or Bio-GHRH analogs for $3 \mathrm{~h}$. The Bio-GHRH was separated by HPLC and different fractions were tested for their potency. Bio-GHRH-2, which was monobiotinylated on the $\varepsilon$-Lys ${ }^{21}$ was nearly as potent as GHRH. * , significantly different from control $(\bigcirc)$ values.

\section{Results}

Structural characterization of biotinylated GHRH derivatives

As illustrated in Fig. 1, limited reaction of synthetic rat GHRH with the biotinylating reagent followed by HPLC resulted in the appearance of four major peptide peaks. Amino acid analysis confirmed that peak 1 was unmodified GHRH, whereas the remaining peaks contained biotinylated derivatives. We refer to these derivatives as Bio-GHRH analogs 2, 3 and 4, corresponding to the peak numbers shown in Fig. 1. Stoichiometric amino acid analysis demonstrated that analogs 2 and 3 contained monobiotinylated GHRH derivatives whereas analog 4 was a dibiotinylated GHRH sequence. Rat GHRH contains only one $\varepsilon$-amino group on a lysine residue $\left(\mathrm{Lys}^{21}\right)$ and one free $\mathrm{N}$-terminus, but no hydroxy amino acids located in reactive linear sequences (Miller \& Kurosky 1993, Miller et al. 1997). Consequently, the monobiotinylated analogs 2 and 3 were assumed to contain biotin moieties linked either to the N-terminus or to the side chain of $\mathrm{Lys}^{21}$. Automated amino acid sequence analysis demonstrated that analog 2 had an unblocked $\mathrm{N}$-terminus, indicating that this peptide was biotinylated on Lys $^{21}$ and analog 3 was biotinylated on the $\mathrm{N}$-terminus. The dibiotinylated analog 4 contained biotin moieties on both amino groups.

\section{Potency of Bio-GHRH derivatives}

Dispersed pituitary cells from both male and proestrous female rats were used to test the secretory potency of the three Bio-GHRH derivatives. Figure 2 graphs result from

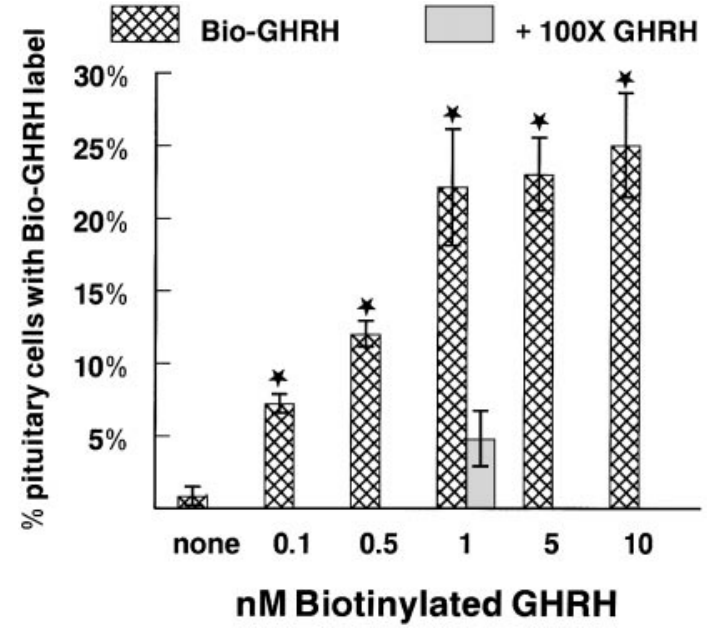

Figure 3 The percentage of pituitary target cells labeled for Bio-GHRH increased with the concentration of the analog to reach a plateau after exposure to $1 \mathrm{nM}$ for $10 \mathrm{~min}$. Addition of 100 times the amount of non-biotinylated GHRH reduced labeling to levels not different from the control values (no Bio-GHRH) indicating that GHRH competed for binding sites. *, significantly different from control values.

one of the three populations of male rat pituitary cells. In this particular experiment, we compared three analogs of Bio-GHRH with the non-biotinylated GHRH. The results showed that the potency of analog 2 was nearly equal to that of native GHRH except at $10 \mathrm{nM}$ (Fig. 2). Analogs 3 and 4 were less potent, which is consistent with the fact that analog 3 had biotin on the $\mathrm{N}$-terminus and analog 4 was dibiotinylated. Analog 2, which had the unblocked N-terminus, was then used for all subsequent studies. The GH levels following $0.1 \mathrm{nM}$ GHRH or Bio-GHRH-2 were lower than those after exposure to 1-10 nM. Note that the lower concentration of GHRH elicits higher levels of $\mathrm{GH}$ from these cells when compared with levels from the Bio-GHRH-treated populations; however, levels after 1 and $5 \mathrm{nM}$ are comparable. Data from another experiment with proestrous female rat pituitary cells are published in a recent methods paper (Childs 1998). In this group of cells, 0.5-10 nM Bio-GHRH was slightly more potent than equal concentrations of GHRH.

Finally, in parallel studies of gonadotropin secretion run with these experiments, neither GHRH nor Bio-GHRH stimulated LH or FSH release even at maximal concentrations of $10 \mathrm{nM}$. However, in more recent studies of enriched somatotrope populations taken from proestrous rats, $0 \cdot 5-10 \mathrm{nM}$ GHRH stimulated a 2 -fold increase in LH release, which was not dose dependent (G V Childs, G Unabia \& D Rougeau, unpublished observations; abstract submitted to the 1999 meeting of the Endocrine Society). 


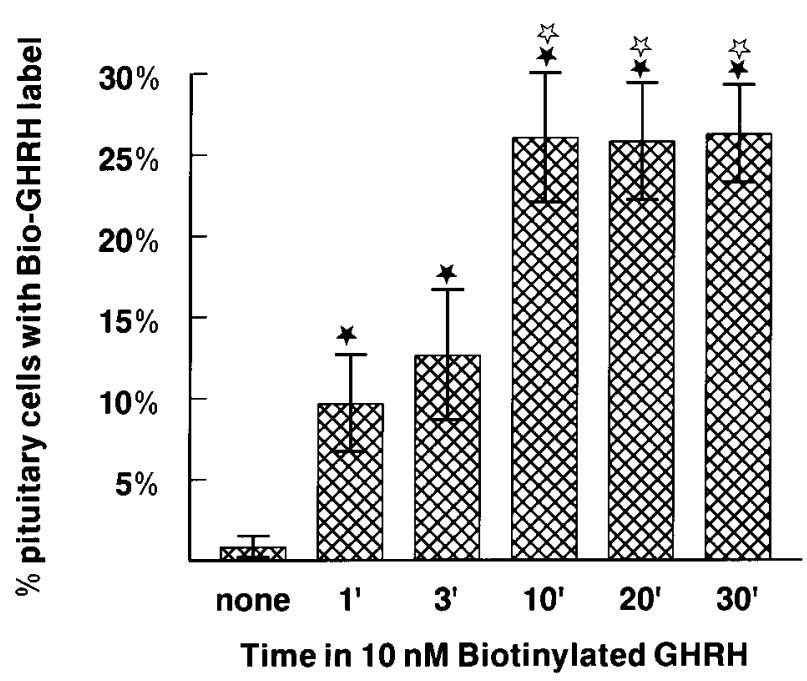

Figure 4 The percentage of pituitary target cells labeled for Bio-GHRH increased with time of exposure to reach a plateau by $10 \mathrm{~min} . \star$, significantly different from control (none) मे, significantly different from 3' example.

\section{Detection of Bio-GHRH target cells}

Labeling was detected on $7 \%$ of pituitary cells from male rats after only $10 \mathrm{~min}$ exposure to $0.1 \mathrm{nM}$ BioGHRH (Fig. 3). This value was significantly greater than the labeling seen after exposure to media alone $(0 \cdot 9-1 \cdot 3 \%)$ or media containing $1 \mathrm{nM}$ Bio-GHRH and $100 \mathrm{nM}$ GHRH. Figure 3 also shows that there was a steady increase in the percentage of labeled cells as the concentration of the Bio-GHRH increased, to reach a plateau of $26-29 \%$ of pituitary cells at $1 \mathrm{nM}$.

Figure 4 shows the results of tests that determined optimal times of exposure. When cells from male rats were exposed to $10 \mathrm{nM}$ Bio-GHRH for 1-3 min, about half of the population (9-12\%) was labeled. Maximal labeling of target cells was seen after $10 \mathrm{~min}$. Similar results were seen in the populations of cells from the female rats; about half the cells were labeled after exposure to $0.5 \mathrm{nM}$ for $10 \mathrm{~min}$ (Childs 1998). Thus, 10 min was the optimal time used for all subsequent experiments.

Figure 3 also shows that the addition of $100 \mathrm{nM}$ native GHRH to $1 \mathrm{nM}$ Bio-GHRH competed for binding sites and reduced the labeling from $27-29 \%$ of the population to $4 \cdot 6 \pm 2 \cdot 0 \%$ (means \pm s.D.) (proestrous female cell populations; Childs 1998) or $4 \cdot 0 \pm 0 \cdot 8 \%$ (male cell populations, Fig. 3). These controls were repeated in subsequent experiments that also included tests of $\mathrm{CRH}$ (a peptide similar in size to GHRH) and GnRH (a decapeptide). Figure 5 illustrates the results representing one of three experiments. Control values show $28 \pm 4 \%$ of cells from male rats labeled for Bio-GHRH. As in previous experiments, $100 \mathrm{nM}$ or $1 \mu \mathrm{M}$ GHRH competed for binding sites and reduced labeling to $5 \cdot 0 \pm 0 \cdot 3 \%$ or $6 \cdot 0 \pm 3 \%$ of the

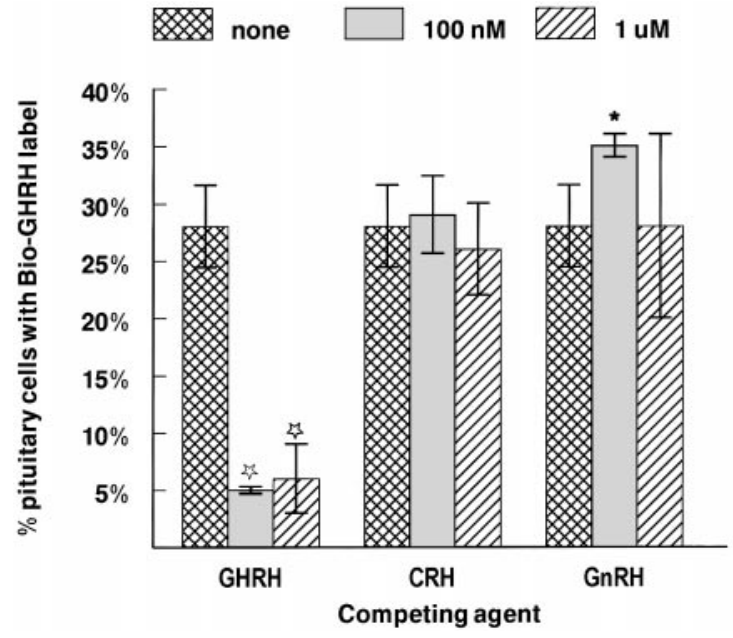

Figure 5 The competition and specificity tests were continued by exposing cells to $1 \mathrm{nM}$ Bio-GHRH for 10 min with and without $100 \mathrm{nM}$ or $1 \mu \mathrm{M} \mathrm{GHRH}, \mathrm{CRH}$ or $\mathrm{GnRH}$. As in the experiment in Fig. 3, GHRH competed for binding sites and reduced the percentage of labeled cells to $5-6 \%$ of the population. $\mathrm{CRH}$ and $1 \mu \mathrm{M}$ GnRH had no effect on binding by biotinylated GHRH. However, simultaneous exposure to $100 \mathrm{nM} \mathrm{GnRH}$ and $1 \mathrm{nM}$ GHRH increased significantly the percentages of cells that bound Bio-GHRH. $\vec{n}$, significantly different from control (Bio-GHRH only).

population respectively. However, neither GnRH nor $\mathrm{CRH}$ competed for binding sites at either concentration tested. Furthermore, the lower concentration of GnRH $(100 \mathrm{nM})$ appeared to increase the percentages of cells that bound GHRH to $35 \pm 1 \%$.

\section{Identification of the hormone content of GHRH target cells}

The dual labeling analysis determined the percentages of GHRH target cells that contained each of the pituitary hormones. This provided data about the proportion of each pituitary cell type that bound the Bio-GHRH. Figure 6 shows the results of this analysis in the three experimental groups. In all groups, $76-80 \%$ of GHRH target cells contained GH antigens. This reflected GHRH binding by $77 \pm 5 \%$ of GH cells in the male rat and $85-90 \%$ of $\mathrm{GH}$ cells in the two groups of female rats (Fig. 6). There were no differences in percentages of dual-labeled GHRH target cells that contained GH when the percentages from the three groups were compared. As we have shown previously (Ibrahim et al. 1986), GH cells represent 26-31\% of the cell population, which correlates well with the percentages of GHRH target cells (25-28\%).

Thus, whereas there were no differences in the GH, adrenocorticotropin (ACTH) or thyrotropin (TSH) content of GHRH target cells (Fig. 6), there were differences in their expression of prolactin (PRL) and gonadotropin antigens when male and proestrous female rat populations were compared. PRL antigens were detected in $33 \pm 6 \%$ 


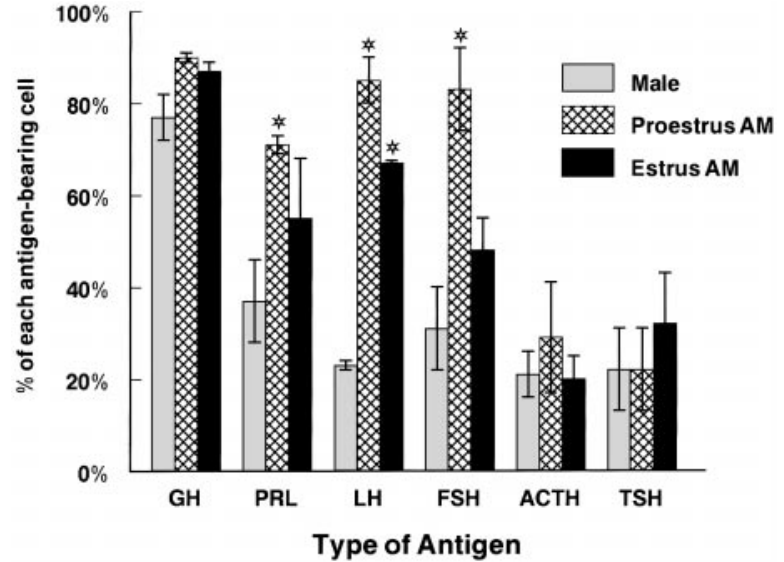

Figure 6 Analysis of dual labeling to learn the percentage of each pituitary cell type that bound Bio-GHRH. Cells with each type of antigen exhibited Bio-GHRH binding. The highest percentages were found among $\mathrm{GH}$ cells and PRL cells or gonadotropes from proestrous female rats. AM=morning. Star, significantly different from male rat values.

of GHRH target cells in male rats $(37 \pm 9 \%$ of PRL cells, Fig. 6). In cells from proestrous female rats, expression of PRL was increased to over half of that of GHRH target cells $(55 \pm 6 \%)$, which reflects expression of GHRH binding by $71 \pm 2 \%$ of PRL cells. The values for the estrous population were not different from those in the male rat population.

When gonadotropins were detected in male rats, $12 \pm 1 \%$ and $18 \pm 5 \%$ of GHRH-target cells stored $\mathrm{LH}$ or FSH respectively $(23 \pm 1 \%$ of $\mathrm{LH}$ cells and $31 \pm 9 \%$ of FSH gonadotropes). In contrast, in cells from proestrous rats, $56 \pm 13 \%$ of GHRH-reactive cells stored FSH $\beta$ and $66 \pm 11 \%$ of these cells stored LH $\beta$ (reflecting GHRH binding to $83 \pm 9 \%$ of FSH cells and $85 \pm 5 \%$ of LH cells, Fig. 6). In estrous females, these values were reduced to values similar to those in the male rat population.

Most of the changes in the GHRH target cell expression of gonadotropin and PRL antigens contribute to changes in the percentages of these gonadotropin or PRL cells in the overall pituitary. Figure 7 shows a graph of the data expressed as percentage of dual-labeled cells in the overall pituitary to highlight the impact of the different GHRH target cell types. In male rat pituitaries, less than $3 \%$ of the cell population bound Bio-GHRH and stored $\mathrm{LH}, \mathrm{FSH}, \mathrm{ACTH}$ or TSH. These same low values for ACTH and TSH cells are seen in both female rat populations as well. However, in the proestrous cell population, there is a 5 -fold increase in the percentage of cells that bound Bio-GHRH and stored gonadotropins (to nearly $14-17 \%$ of pituitary cells) when values are compared with those in the other two groups.

Normally, gonadotropes represent $14 \%$ of the pituitary cell population in male rats and $16-18 \%$ in proestrous female rats. Furthermore, as reported previously, the loss of

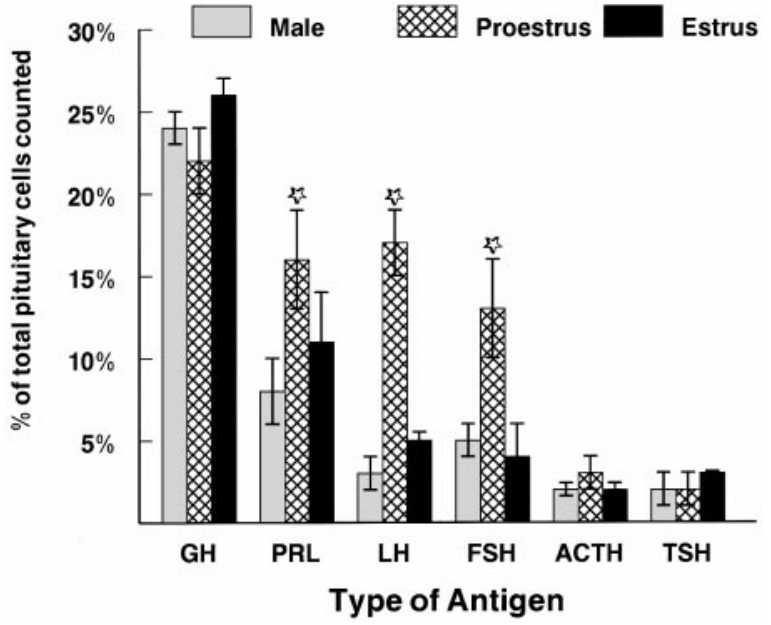

Figure 7 Analysis of dual labeling to learn the percentages of the overall cell population of cells that bound Bio-GHRH and stored a given pituitary hormone. The predominant cell type was the $\mathrm{GH}$ cell. However, in proestrous female rats, significant percentages of cells expressed binding for Bio-GHRH and PRL, or gonadotropin antigens. Star, significantly different from male rat values.

hormone stores during late proestrus and early estrus caused a decline in the percentages of gonadotropes to 7-8\% by the morning of estrus (Childs et al. 1987, 1992a,b, 1994a). Thus, the loss in percentages of cells with GHRH binding and gonadotropins in the overall pituitary population (Fig. 7) reflects this decline. However, in spite of this reduced overall expression in the pituitary cell population, $40-60 \%$ of the remaining gonadotropes retained the capacity to bind the Bio-GHRH (Fig. 6).

Figures 8 and 9 are photomicrographs illustrating the binding of Bio-GHRH by LH and FSH cells from proestrous female rats. It shows the variation in the binding pattern after $10 \mathrm{~min}$. Some cells have patchy labeling over the cell periphery. Other cells are lightly labeled, if at all. The distinct amber-orange label of the hormone antigens is evident where there is no Bio-GHRH. A mixture of Bio-GHRH and antigens causes a blend of orange and dark black/blue.

\section{Discussion}

This study was stimulated by a set of findings from our laboratory reported in 1994 which showed that, during late diestrus and early proestrus, a subpopulation of $\mathrm{GH}$ cells expressed LH and FSH mRNAs and GnRH receptor activity (Childs et al. 1994a,b). The most recent reports showed that the expression of GnRH receptors could be altered by inhibin or activin pretreatment (Childs \& Unabia 1997, Childs et al. 1997).

Activin stimulates the release and synthesis of FSH (Ling et al. 1986, Vale et al. 1986, Carrol et al. 1988, 
Kitaoka et al. 1988). Less striking effects are also seen on LH secretion (Kitaoka et al. 1988, Vale et al. 1988, Knight 1996). It also has inhibitory effects on GH, decreasing proliferation, synthesis and release (Knight 1966, Kitaoka et al. 1988, Bilezikjian et al. 1990, Billestrup et al. 1990, Struthers et al. 1992). Because of activin's stimulation of $\mathrm{GnRH}$ receptor expression by gonadotropes (reviewed in Childs \& Unabia 1997), we hypothesized that it might be partially responsible for the transitional conversion of somatotropes to gonadotropes. Furthermore, because of activin's inhibitory effects on somatotropes, we hypothesized that the developing somatogonadotropes might show reduced expression of somatotropic phenotypes.

To study expression of GHRH receptors, we developed techniques that detected target cells for a biotinylated analog of GHRH. This analog was purified by HPLC and various fractions were tested by RIA for their potency in assaying $\mathrm{GH}$ secreted into media in vitro. A comparison of the fractions shows the effect of biotinylation on the biological activity. It is important to note that even limited biotinylation of rat GHRH can result in several different modified derivatives, only one of which (analog 2) possessed a biological potency equivalent to GHRH (Figs 1 and 2). As analog 2 was modified on $\mathrm{Lys}^{21}$, whereas the less potent analogs 3 and 4 were biotinylated at the $\mathrm{N}$-terminus, our data are consistent with previous studies which have demonstrated that the N-terminus of GHRH is critical for biological activity (Campbell et al. 1995).

\section{Cytochemical detection of Bio-GHRH}

The cytochemical data do not support the hypothesis that suggests loss of the GH phenotype. There are no differences in the percentage of GHRH target cells or the percentages of those that contain GH when male and female rats are compared. Furthermore, the GHRH target cells express more gonadotropins during proestrus, when the somatogonadotropes are abundant. Studies that tested biopotency of Bio-GHRH and compared secretion of GH in response to GHRH or Bio-GHRH showed no difference in responses from male rat or proestrous rat populations, indicating no loss in functional GHRH receptors or GH secretory activity (Fig. 2; Childs 1998, Childs GV, Unabia G \& Rougeau D, unpublished observations; abstract submitted to the 1999 meeting of the Endocrine Society). Also, the immunocytochemical studies showed no losses in GH cells when populations from male rats and proestrous female rats were compared. Thus, we can find no support for the hypothesis that there is a decline in $\mathrm{GH}$ cell function as the cells become transitional gonadotropes.

The analysis of cells exposed to single-labeling protocols showed that Bio-GHRH-labeled cells are $26-32 \%$ of the pituitary cell population. These values are similar to those reported by Villalobos et al. (1997), when they detected GHRH-responsive cells by their increase in intracellular calcium. In their study, $36 \%$ of male rat pituitary cells responded to GHRH. When they identified the responsive cells by immunolabeling, they reported that multiple cell types were involved, including cells with GH, PRL and FSH antigens. Their dilution tests ruled out the possible presence of paracrine factors that might have mediated the effects of GHRH.

\section{Significance of GHRH receptor expression by PRL cells}

The PRL content of cells with Bio-GHRH receptors is not surprising in view of the well-documented information about co-storage of PRL and GH. Studies since the early 1980s have described cells that produce and secrete both PRL and GH antigens (Boockfor et al. 1986). They represent about $7 \%$ of the cell population in male rat pituitary cells. This value is similar to the percentage of pituitary cells in male rats that bind GHRH and contain PRL antigens (8\%) reported in the present study (Fig. 7).

Furthermore, the proportion of these mammosomatotropes changes with the physiological state. In studies of pregnant rats by Porter et al. (1991), increases in the proportion of cells that secrete PRL coincide with comparable decreases in GH cells as pregnancy progresses and lactation begins. This process is reversible as lactation ceases. Thus, the data suggest that the PRL and GH secretory cells are functionally interconvertible. GHRH may be one regulatory factor that facilitates this conversion.

Recently, changes in numbers of mammosomatotropes with the estrous cycle were tested in bovine pituitaries by Kineman et al. (1991). When they calculated the percentages of cells that released both GH and PRL, the highest co-secretors were found just before and after ovulation (during the follicular phase and during the early luteal phase). The rise in PRL secretors seen just after ovulation was at the expense of cells secreting GH. Similarly, in the mid-luteal phase, there is a fall in PRL secretors coinciding with a rise in GH secretors. Again, their data supported the concept that there was a bidirectional conversion between GH and PRL secretors. The timing of the highest expression of co-secretion fits well with the present studies in which we show expression of PRL by Bio-GHRHreceptive cells just before ovulation in the rat. The proestrus values are 1.5- to 2-fold higher than those reported for the male rat population $(37 \%)$.

Finally, whereas it is assumed that GHRH may function to release $\mathrm{GH}$ from mammosomatotropes, GHRH may also stimulate PRL release (Arimura et al. 1983, Law et al. 1984, Stachura et al. 1985). More recent evidence for functional GHRH receptors on cells with PRL antigens was reported by Villalobos et al. (1997). These workers showed that GHRH stimulated calcium increases in over $40 \%$ of PRL cells from 8- to 10 -week-old male rats. This value is comparable to that seen in the present studies of male rat cell populations. Figure 6 shows that $37 \pm 9 \%$ of PRL cells in male rats bind GHRH. Thus, the present 

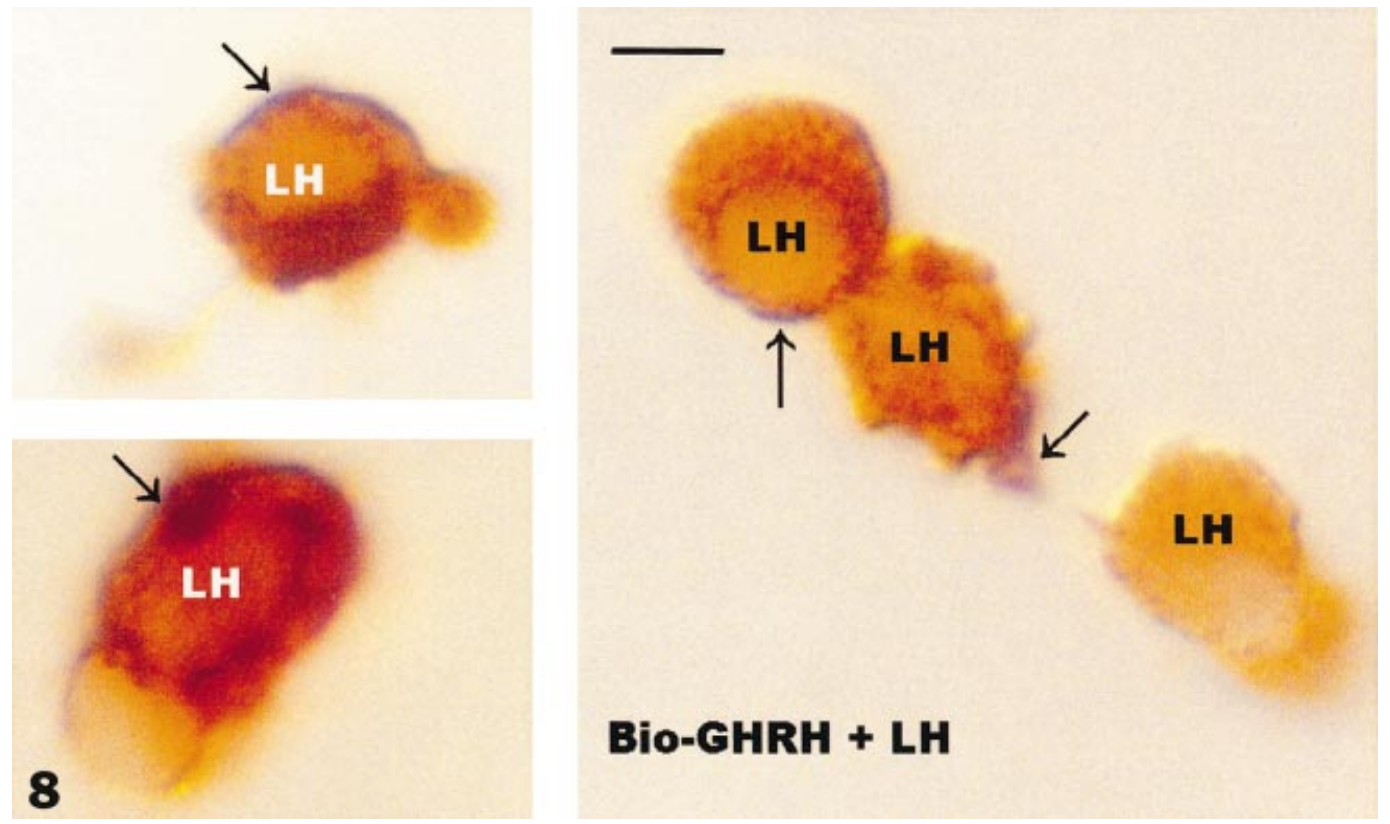

Figure 8 Dual labeling for Bio-GHRH (dark blue-black) and LH (orange-amber in gonadotropes from proestrous female rats. The labeling shows the variation in pattern typically seen in these cells. Most of it is peripheral, but sometimes it appears in patches or a cap at one edge of the cell. Some cells are mostly devoid of label for Bio-GHRH and appear purely orange. Other cells have a dense accumulation over the entire cell. Magnification $\times 250$. Bar $=10 \mu \mathrm{m}$.
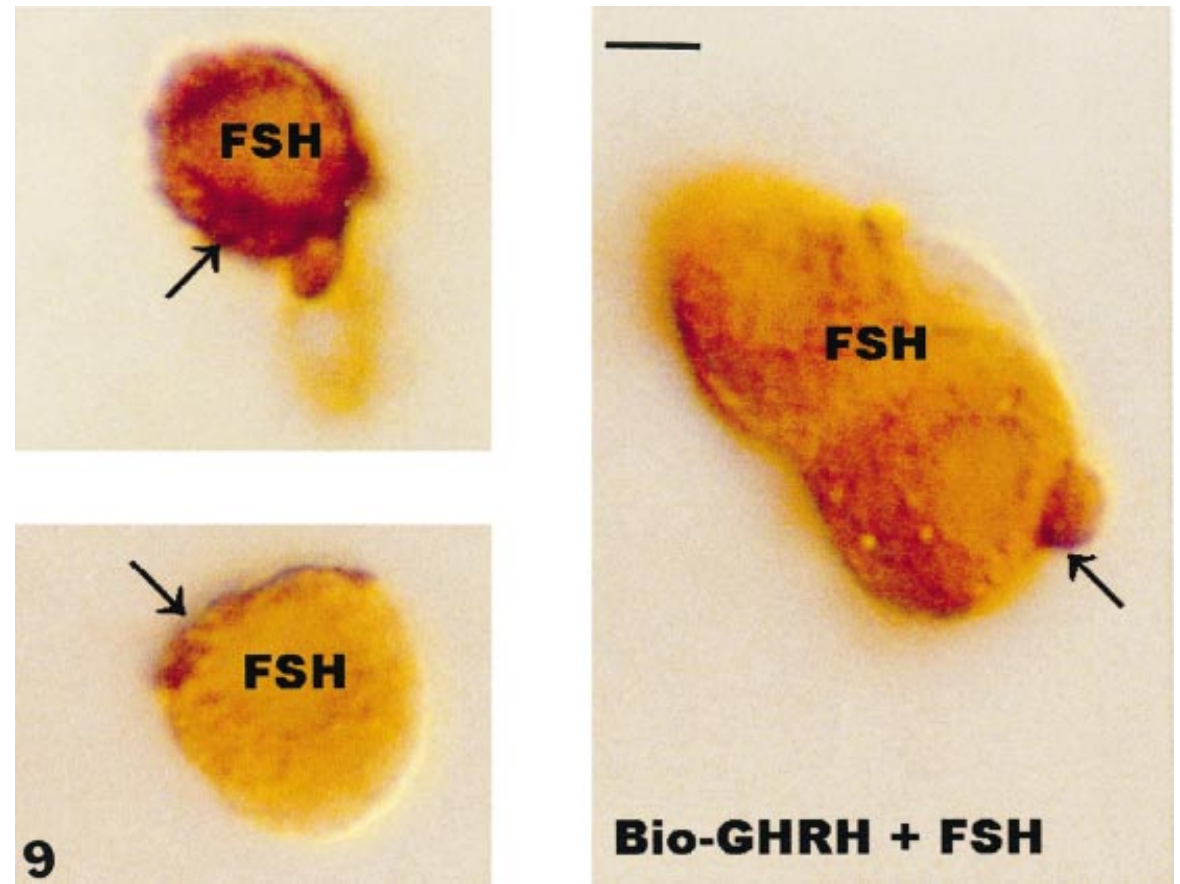

9

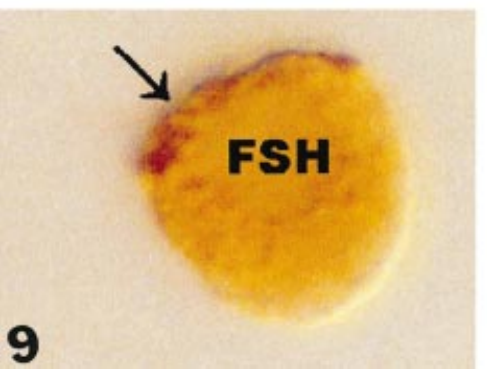

\section{BIo-GHRH + FSH}

Figure 9 Dual labeling for Bio-GHRH (dark blue-black) and FSH in gonadotropes from proestrous female rats. The labeling shows the variation in pattern typically seen in these cells. Most of it is peripheral, but sometimes it appears in patches or a cap at one edge of the cell. Some cells are mostly devoid of label for Bio-GHRH and appear purely orange. Other cells have a dense accumulation over the entire cell. Magnification $\times 250$. Bar $=10 \mu \mathrm{m}$. 
report adds to the growing body of literature describing the regulation and conversion of mammosomatotropes. We add new findings showing that the cells express GHRH receptors.

\section{Significance of GHRH binding by gonadotropes}

The current findings add to evidence from our studies of the somatogonadotrope in 1994 (Childs et al. 1994a,b) by showing that the transitional somatogonadotrope retains GHRH binding activity. Detection of gonadotropin antigens in GHRH target cells also points to the fact that the mRNAs found in our earlier studies of $\mathrm{GH}$ cells (Childs et al. 1994a) are translated. This work also correlates with an earlier study by Knepel et al. (1987). They were studying GHRH-mediated dynorphin secretion and found that the same concentration of GHRH that released dynorphin also released $\mathrm{LH}$ and $\mathrm{FSH}$ from male rat pituitary quarters. The minimal concentration of GHRH (10-100 nM) needed for detectable gonadotropin release was 100 times the minimum required to release $\mathrm{GH}$ $(0 \cdot 1 \mathrm{nM})$. They found that a GnRH antagonist reduced GHRH-stimulated LH or FSH secretion by about $50 \%$. These data suggest that GHRH can elicit the release of $\mathrm{LH}$ and FSH from male rat pituitary cells. We agree that GHRH can serve as a limited secretagogue for $\mathrm{LH}$, especially in cells from proestrous rats (Childs G, Unabia G \& Rougeau D, unpublished observations; submitted as abstract to the 1999 meeting of the Endocrine Society).

Furthermore, Knepel et al. (1987), reported that an iodinated $\mathrm{GnRH}$ antagonist was completely displaced by GHRH at concentrations that were 425-fold higher than the $K_{\mathrm{d}}$ of $\mathrm{GnRH}$ antagonist itself. They suggested that GHRH was binding to GnRH receptors. Our findings suggest that, since over $78 \%$ of GHRH target cells contain $\mathrm{GH}$, it is likely that the GHRH is binding to functional GHRH receptors on GH cells. Nevertheless, we ran competition tests to learn if GHRH could be displaced by GnRH. We showed that, whereas the binding by $1 \mathrm{nM}$ is displaced by $100 \mathrm{nM} \mathrm{GHRH}$ it is not affected by equal or higher amounts of D-Lys ${ }^{6}-\mathrm{GnRH}$. Thus, GnRH does not appear to compete for the sites occupied by Bio-GHRH. In fact, the addition of GnRH appears to increase the percentage of GHRH target cells from 28 to 35\%. These data correlate with recent secretion studies in which we found that $\mathrm{GnRH}$ has an additive effect on GHRHmediated secretion of $\mathrm{GH}$ (Childs G, Unabia G \& Rougeau D, unpublished observations; submitted as an abstract to the 1999 meeting of the Endocrine Society). The effects are particularly striking in the cells from proestrous females. The addition of $\mathrm{GnRH}$ with $0.5 \mathrm{nM}$ GHRH may increase GH levels from 12 times control values seen with GHRH alone to 19 times control values. The secretory data suggest that the two receptors may act both independently and cooperatively to release both GH and gonadotropins.
Further evidence for functional GHRH receptors on cells with gonadotropin antigens is found in the study by Villalobos et al. (1997) in which calcium influx was measured in populations from 8 - to 10 -week-old male rats. After the responsive cells were identified by immunolabeling for pituitary antigens, the analysis showed that $3 \%$ of FSH cells were responsive to both GnRH and GHRH; 8\% were responsive to GnRH, GHRH and TRH; and 17\% were responsive to GnRH, GHRH, TRH and CRH. Adding these percentages, one finds that $28 \%$ of FSH cells respond to GHRH. This correlates well with our values (Fig. 6), which show that $31 \pm 3 \%$ of FSH cells bind GHRH in male rats.

\section{The multipotential somatotrope}

An analysis of the data in Fig. 7 points to considerable overlap in hormone storage in the pituitary cell population. As shown in Figs 3 and 4, maximal labeling for BioGHRH is found in $26-30 \%$ of the cell population. However, if one adds the percentages of each cell type labeled for Bio-GHRH in Fig. 7, the sum is more than twice the actual percentages of GHRH target cells for the male rat alone and over three times those for the proestrus female. Since there are no differences in GH or GHRH target cells in these three groups and $78-80 \%$ of the GHRH target cells contain GH, one must assume that the GHRH-receptive somatotrope has developed the capacity to produce PRL as well as LH and FSH. This expands the function of the mammosomatotrope and suggests that this multifunctional cell is prepared to support gonadotropin, $\mathrm{GH}$ and PRL needs of the reproductive system. The potential may also be there in the male rat as well, since the data reported by Villalobos et al. (1997) show that 17\% of cells with FSH antigens respond to GHRH, GnRH and TRH. Our studies found that $18 \%$ of cells with FSH antigens bound GHRH. Furthermore, 14\% of GH cells respond to combinations of GHRH, GnRH and TRH with or without $\mathrm{CRH}$.

\section{Summary and conclusions}

The original working hypothesis that led to this study stated that the conversion of the transitional somatogonadotrope seen during late diestrus/early proestrus (Childs et al. 1994a,b, Childs \& Unabia 1997), may coincide with a reduction in somatotropic functions. The present study focused on expression of GHRH receptors by somatotropes comparing populations during the peak period of expression of gonadotropic activity (proestrous morning) with male rats and female rats in estrus. Expression was detected cytochemically with a biotinylated GHRH analog followed by immunolabeling to detect the hormone content of the target cell. Bio-GHRH bound to $26-30 \%$ of the cell population. Most GHRH target cells 
stored GH and over a third stored PRL antigens in the male. However, in the proestrous female rat over half of the target cell populations stored PRL and gonadotropins. This high expression occurs at the same time that GH cells express LH $\beta$ and FSH $\beta$ mRNA. Therefore, the findings did not support the original working hypothesis that postulated a reduction in somatotropic function in these cells. If activin upregulates expression of $\mathrm{GnRH}$ receptors by these somatotropes in vivo (Childs \& Unabia 1997), it does not do so at the expense of GHRH receptivity. Finally, these studies provided information that supports the concept that there is a subset of multipotential cells that may interconvert by producing PRL and gonadotropins depending on the needs of the animal.

\section{Acknowledgements}

The authors would like to acknowledge the technical assistance of Diana Rougeau. We also thank A F Parlowe and the Hormone Distribution program for the RIA kits (GH, LH and FSH). We thank Dr J B Pierce for the anti-bovine LH- $\beta$ used in this study. This study was presented in abstract form and in a poster session at the 1998 meetings of the Endocrine Society. The study was supported by NIH R01 HD 15472 and R01 HD 33915.

\section{References}

Arimura A, Culler MD, Turkelson CM, Luciano MG, Thomas CR, Obara N, Groot K, Rivier J \& Vale W 1983 In vitro pituitary hormone releasing activity of 40 residue human pancreatic tumor growth hormone releasing factor. Peptides 4 107-110.

Bilezikjian LM, Corrigan AZ \& Vale W 1990 Activin-A modulates growth hormone secretion from cultures of rat anterior pituitary cells. Endocrinology 126 2369-2376.

Bilezikjian LM, Corrigan AX \& Vale WW 1993 Activin-B, inhibin-B and follistatin as autocrine/paracrine factors of the rat anterior pituitary. In Proceedings of the Second International Symposium on Inhibin and Inhibin-related Peptides. Challenges in Endocrinology and Modern Medicine, pp 1-19. Ed. HG Burger. Sienna, Italy.

Billestrup N, Gonzalez-Manchon C, Potter E \& Vale W 1990 Inhibition of somatotroph growth and growth hormone biosynthesis by activin in vitro. Molecular Endocrinology 4 356-362.

Boockfor FR, Hoeffler JP \& Frawley LS 1986 Analysis by plaque assays of $\mathrm{GH}$ and prolactin release from individual cells in cultures of male pituitaries. Neuroendocrinology 42 64-70.

Campbell RM, Bongers J \& Felix AM 1995 Rational design, synthesis, and biological evaluation of novel growth hormonereleasing hormone analogues. Biopolymers 37 67-88.

Carrol RS, Corrigan AZ, Gharib SD, Vale W \& Chin WW 1988 Inhibin, activin and follistatin: Regulation of follicle stimulating hormone messenger ribonucleic acid levels. Molecular Endocrinology 3 1969-1976.

Childs GV 1994 Division of labor among gonadotropes. Vitamins and Hormones 50 217-283.

Childs GV 1997 Cytochemical studies of multifunctional gonadotropes. Microscopy Research and Techniques 39 114-130.

Childs GV 1998 Identification of biotinylated ligands on specific target cells in the pituitary: studies of regulation of binding. In Methods in Neuroendocrinology, pp 31-48. Ed. LD Van de Kar. Boca Raton, FL: CRC Press.
Childs GV \& Unabia G 1997 Cytochemical studies of the effects of activin on gonadotropin releasing hormone $(\mathrm{GnRH})$ binding by pituitary gonadotropes and growth hormone cells. Journal of Histochemistry and Cytochemistry 45 1603-1610.

Childs GV, Naore Z, Hazum E, Tibolt R, Westlund KN \& Hancock MB 1983 Cytochemical characterization of pituitary target cells for biotinylated gonadotropin releasing hormone. Peptides 4 549-555.

Childs GV, Unabia G, Tibolt R \& Lloyd JM 1987 Cytological factors that support nonparallel secretion of LH and FSH during the estrous cycle. Endocrinology 121 1801-1813.

Childs GV, Unabia G \& Lloyd J 1992a Recruitment and maturation of small subsets of luteinizing hormone (LH) gonadotropes during the estrous cycle. Endocrinology 130 335-345.

Childs GV, Unabia G \& Lloyd JM 1992b Maturation of FSH gonadotropes during the rat estrous cycle. Endocrinology 131 29-36.

Childs GV, Unabia G \& Rougeau D 1994a Cells that express luteinizing hormone ( $\mathrm{LH}$ ) and follicle stimulating hormone (FSH) beta $(\beta)$ subunit mRNAs during the estrous cycle: The major contributors contain LH $\beta$, FSH $\beta$ and/or growth hormone. Endocrinology 134 990-997.

Childs GV, Unabia G \& Miller BT $1994 b$ Cytochemical detection of GnRH binding sites on rat pituitary cells with LH, FSH and GH antigens during diestrous upregulation. Endocrinology 134 1943-1951.

Childs GV, Miller B \& Miller W 1997 Differential effects of inhibin on gonadotropin stores and gonadotropin releasing hormone binding to pituitary cells from cycling female rats. Endocrinology $\mathbf{1 3 8}$ $1577-1584$

Ghosh BR, Wu JC, Childs GV \& Miller WL 1996 Inhibin and estradiol alter gonadotropes differentially in ovine pituitary cultures: Changing gonadotrope numbers and calcium responses to gonadotropin-releasing hormone. Endocrinology 137 5144-5154.

Ibrahim SN, Moussa SM \& Childs GV 1986 Morphometric studies of rat anterior pituitary cells after gonadectomy: Correlation of changes in gonadotropes with serum levels of gonadotropins. Endocrinology 119 629-637.

Kineman RD, Faught WJ \& Frawley LS 1991 Mammosomatotropes are abundant in bovine pituitaries: influence of gonadal status. Endocrinology 128 2229-2233.

Kitaoka M, Kojima I \& Ogata E 1988 Activin-A: Modulator of multiple types of anterior pituitary cells. Biochemical and Biophysical Research Communications 157 48-54.

Knepel W, Schwaninger M, Wesemeyer G, Dohler KD \& Sandow J 1987 Effect of human growth hormone-releasing hormone on the release of dynorphin-like immunoreactivity, luteinizing hormone and follicle stimulating hormone from rat adenohypophysis in vitro. Endocrinology 120 732-738.

Knight PG 1996 Roles of inhibins, activins and follistatin in the female reproductive system. Frontiers in Neuroendocrinology 17 476-509.

Law GJ, Ray KP \& Wallis M 1984 Effects of growth hormonereleasing factor, somatostatin, and dopamine on growth hormone and prolactin secretion from cultured ovine pituitary cells. FEBS Letters 166 189-193.

Ling N, Ying S-Y, Ueno N, Shimasaki S, Esch F, Hotta N \& Guillemin R 1986 Pituitary FSH is released by a heterodimer of the $\beta$-subunits from the two forms of inhibin. Nature 321 779-782.

Lloyd JM \& Childs GV 1988 Changes in the number of GnRH receptive cells during the rat estrous cycle: biphasic effects of estradiol. Neuroendocrinology 48 138-146.

Miller BT \& Kurosky A 1993 Elevated reactivity of seryl hydroxyl groups within the linear peptide triads His-Xaa-Ser or Ser-Xaa-His. Biochemical and Biophysical Research Communications 196 461-467.

Miller BT, Collins TJ, Nagle GT \& Kurosky A 1992 The occurrence of $\mathrm{O}$-acylation during biotinylation of gonadotropin releasing hormone and analogs: evidence for a reactive serine. Journal of Biological Chemistry 267 5060-5069. 
Miller BT, Collins TJ, Rogers ME \& Kurosky A 1997 Peptide biotinylation with amine-reactive esters: differential side chain reactivity. Peptides 18 1585-1595.

Porter TE, Wiles CD \& Frawley LS 1991 Evidence for bidirectional interconversion of mammotropes and somatotropes: rapid reversion of acidophilic cell types to pregestational proportions after weaning. Endocrinology 129 1215-1220.

Smith JS, Miller BT \& Kurosky A 1991 Biotinylated peptides/ proteins: II. Identification of biotinylated lysyl phenylthiohydantoins. Analytical Biochemistry 197 254-257.

Stachura ME, Tyler JM \& Farmer PK 1985 Human pancreatic growth hormone-releasing factor-44 differentially stimulates release of stored and newly synthesized rat growth hormone in vitro. Endocrinology 116 698-706.

Struthers SR, Gaddy-Kurten D \& Vale WW 1992 Activin inhibits binding of transcription factor Pit-1 to the growth hormone promoter. Proceedings of the National Academy of Sciences of the USA 89 11451-11455.
Vale W, Rivier J, Vaughan J, McClintock R, Corrigan A, Woo W, Karr D \& Spiess J 1986 Purification and characterization of an FSH-releasing protein from porcine ovarian follicular fluid. Nature $321776-779$.

Vale W, Rivier C, Hsueh A, Campen C, Meunier H, Bicsak T, Vaughan J, Corrigan A, Bardin W, Sawchenko P, Petraglia F, Yu J, Plotsky P, Spiess J \& Rivier J 1988 Chemical and biological characterization of the inhibin family of protein hormones. Recent Progress in Hormone Research 44 1-34.

Villalobos C, Nunez L, Frawley LS, Garcia-Sancho J \& Sanchex A 1997 Multiresponsiveness of single anterior pituitary cells to hypothalamic-releasing hormones: a cellular basis for paradoxical secretion. Proceedings of the National Academy of Sciences of the USA 94 14132-14137.

Received 26 November 1998

Accepted 8 March 1999 